Paweł BARTOSZCZUK

System Research Institute of the Polish Academy of Science

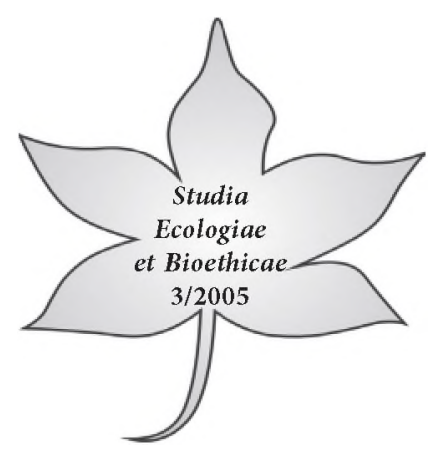

\title{
The Impact of Economic growth on environmental quality
}

\section{Introduction}

This paper examines the possible impact of economic development on environmental quality. Certain plausible assumptions about the response of some variables are made. We present possible scenarios, including irreversible decrease of non-renewable resources. In describing an economic and environmental model we focus on the relations among income, pollution, and non-renewable resources. Next, we present the simulation runs of the model, conducted with the help of existing system dynamics modeling tools.

The paper consists of 5 chapters including introduction. We present opinions on the influence of economic development on environment, with the stress on the Club of Rome ideas in the chapter 2 . In chapter 3 we describe relations in our model, and we present the results of our simulations and conclusion in chapters 4 and 5.

\section{The different viewpoints on growth and environment}

In the debate over growth and environment, we have two views: optimistic and pessimistic. Proponents of optimistic view argue that continued economic growth will produce less polluted, and more resource rich world (Ophardt, 1997). Beckermann (1999) claims that growth is beneficial due to supporting social improvement. Stiglitz (1996) suggests that the elasticity of substitution between two inputs: capital and resources is sufficiently large with new technologies. Lovejoy (1996) imply that technology can change substitution over time so there is less scarcity. Mikesell (1995) emphasizes the lack of evidence that growth leads to lower productivity.

Some other researchers indicate that for a specific kinds of environmental problems the relation between income and the level of environmental pressure shows an inverted U curve (Arrow, at al. 1995; de Bruyn and Heintz, 1999; 
Dinda, 2001; Grossman and Krueger, 1995). The conclusion of those studies can be criticized on several grounds. Results obtained from cross-section data cannot be translated to future time-series for specific countries. Moreover, empirical studies only focus on particular aspects of environmental pressure not related to the carrying capacity natural resilience of ecosystems.

Many researchers are trying to answer a question how to achieve sustainable development, i.e. how to ensure that income of future generation is not lower than that of present generations. Economists have generally seen the provision of man-made capital as the best solution for future generation. This capital consists of factories, machineries, tractors, dams, building, and infrastructure. Economist would argue that sustainability cannot be adopted unless it is in the self interest of individuals. In contrary, neo-Malthusians economists believe that continued capital accumulation, while it might initially increase material welfare, is unsustainable (Tisdell, 2004). Transformation of natural resources into capital leads to pollution. Non-renewable resources, which are applied in production process, are depleted and can be non available in the future. NeoMalthusians argue that the sustainability of future production and welfare depends on stock of natural resources and environmental factors. Therefore it is more important to conserve natural resources rather than further accumulate man-made capital. According to them, man -made capital is becoming less satisfactory as a substitute for resources. Moreover, they argue that unless care is taken, economic growth can increase scarcity in the long term rather than reduce it. Existing environmental stock is becoming more precious as a basis for sustaining economic production and economic welfare. If we wish to sustain the welfare of future generations, we should be wary about irreversibly depleting this stock. However, because the employment of labor in capitalist system depends on the level of economic activity and capital accumulation, the maintaince of labor usually requires continuing economic growth. Economics is concerned with problems arising with social scarcity and ways of solving this problem, mainly by economic growth. However, neo-Malthusian economists believe that this may not be a sustainable strategy and it can result in future poverty.

The sustainability of economic growth has become an increasingly important since population growth and natural resources have been depleted. Tietenberg (2000) distinguish different levels of sustainability: weak, strong and environmental. Weak sustainability requires that natural plus man-made wealth should be available for future generations as to the present generations. Strong sustainability requires that neither the natural wealth and man made wealth may decline over time. Man-made wealth may not be good substitutes for environment. Environmental sustainability suggests that different forms of natural wealth may not be good substitutes and natural resources cannot be depleted. 
Overall, optimists view two things: (1) the elasticity of substitution between an essential resource and capital is greater than 1, and (2) technology will increase the productivity of resources faster than their exhaustion. The empirical literature provides a mixed and partial picture. While some studies yield substitution elasticities greater than unity (a necessary condition for economic growth models to generate sustainable paths) for metal: steel, copper and aluminium (Brown and Field, 1979), others suggest that for scarce materials like beryllium elasticity is close to zero (Deadman and Turner, 1988).

Pessimists claim that sustainability recognizes that without intervention the global environment will not be able to provide a reasonable standard of living (Helm, 2000). Malthus (cited by Solow (2000)), was the first who pointed out the possibility of growing relative scarcity of natural resources. The authors of 'The Limits to Growth' Report continue to argue that economic growth must be lowered along with other changes (Meadows, 1972). The analyses in the report did draw public awareness to the need for saving and conserving the environment and natural resources (Hayami, 1997). Daly (1996) suggested that renewable resources should be used in amount no greater than the rate of regeneration.

Club of Rome Report emphasised the examples of exponential growth: world population has been growing exponentially since the beginning of industrial revolution. In 1991 annual growth rate was estimated as $1.7 \%$, which means a doubling time of 40 years. Also world production, relative to the base of 1963 year show clear exponential increase, as well. The concentration of carbon dioxide in the atmosphere has risen from 290 parts per million in the last century to over 350 parts per million and will continue on its exponential growth path. According to Intergovernmental Panel on Climate Change (IPCC), atmospheric $\mathrm{CO} 2$ concentrations by 2100 will be in the range of 650 to $970 \mathrm{ppm}$. The increased atmospheric concentrations of $\mathrm{CO} 2$ and other greenhouse gases (GHG) trap more of the earth's heat, causing temperatures to rise. As a result, it is predicted that the global average surface temperature can rise between 1.4 and 5.8 degrees Celsius between 1990 and 2100, an unprecedented rate of increase. These in turn are responsible for melting ice, rising sea levels, and a greater number of more destructive storms.

The 'Limits to growth' study made a valuable contribution to our knowledge on sustainable development in bringing the implications of unbounded growth at a time when the environmental capacity was often thought to be unlimited. The nature of the policy prescription of the World 3 arises from the way the resources sectors have been modelled. The stocks of these resources have outflow, but not inflow, which causes collapse, since the outflow continue with production.

Acharay and Saeed (1996) modified the "Limits" model first to accommodate the model variety. The modified model generated the behaviour similar to the original model under realistic assumptions, although it contained latent structure 
for arriving at robust equilibrium. When run for longer time, Model "Limits to growth" spell doom, even when their policy recommendation are applied. Hayes (1993) claimed that that policies, which seem to ensure sustainable future could only postpone collapse until middle of next century.

The resources ecosystem of the earth is a relatively small subsystem within the universe and it derives its energy from sun. Most resource policies currently we use fall into reactive category. Implementation of reactive policies requires powerful exogenous intervention. Corrective policies aimed at improving market mechanisms attempt to ensure efficient use of resources. We must emphasize that market mechanism assure only intra-temporal efficiency of resources and they cannot address the issue of inter-temporal equity. Market economy claims that restoring resources for futures makes sense only when the expected resource' future price is increasing at a rate that is at least equal the market rate of interest. Therefore, market mechanisms always favour present use of resources over future one (Saelid, 1996) Understanding the fact that markets may fail to allocate resources properly also favour public intervention to slow down and stretch out the exploitation of resources pool. The model, however, rules out any inputs into global resource system. One could say that the fixed stocks take into account the ultimate available resources, including sun energy, but the time frame of such stocks would be extremely long.

\section{The analysis of main relations}

First, we consider macroeconomic relations with capital, income, consumption, and savings, which can be found in many macroeconomic books (Solow, 2000). Capital is accumulated by the amount of investment and decreased by depreciation in a specified time unit, like one year. We assume all production comes about as a function of capital and labour. The consumption per capita is minimum from consumption per capita and substantial level of consumption. Subtracting consumption from income yield savings. Saving can be changed into investments goods like raw materials, thereby increasing capital stock. At equilibrium, investments have to be equal to saving otherwise output would not be sold out completely or would be in short supply. To warrant a non-negative amount of saving, the saving function is maximum from zero and the difference between output and consumption.

Each year the population is increased by the total number of births that year and decreased by the total number of deaths that that year. Number of working force is proportional to the population. Some relations described above are presented on the Powersim diagram (Figure 1). 


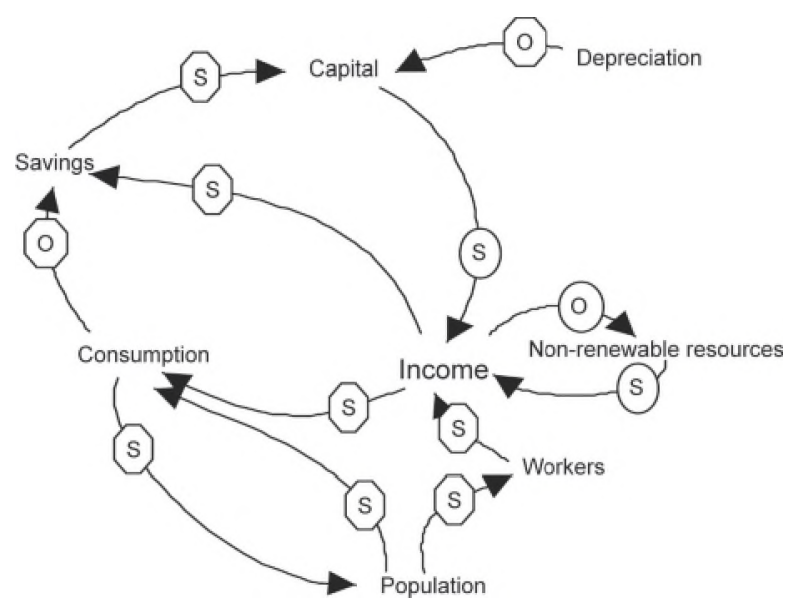

Figure 1.Diagram with reinforcing loop among capital, and income and consumption, and balancing loop between non-renewable resources and income. $\mathrm{S}$ - change in the same direction and $\mathrm{O}$ - change in the opposite direction.

Next, we add to our model fossil fuels. As the world's population and capital grow, the demand for fuels will increase accordingly. The amount of nonrenewable resources (fossil fuels) consumed each year can be found by multiplying the output (income) by usage rate. As population becomes wealthier, it tends to consume more resources per person and year. That input of natural resources to production decreases with time due to application of new technologies enabling effective use of non-renewable fossil fuels. Non-renewable fossil fuels can be replaced with alternative energies generated by wind, hydrogen, solar cells and geothermal sources. Such alternative energies are in turn assumed to be generated by alternative renewable sources. The accumulation of the substitutes (green capital) is done through green investment. The substitutes are subtracted out of the output, and accordingly capital accumulation began to decline with less amount of savings and investment.

Next, we have to distinguish renewability from recyclability. Renewability is related with reproducibility of natural resources themselves. For instance, fossil fuels, once consumed, cannot be reproduced, while rangelands, croplands and fisheries could be repeatedly produced (and used) as well as sources of wind energy (Yamaguchi, 2004). On the other hand, recyclability is related with the re-use of the products of natural resources. For instance, metals from minerals, trees and papers could be repeatedly used, while electricity by any source, as well as meat from rangelands, grains from croplands and fish from fisheries, cannot be re-used. Whenever these distinctions are made, natural resources are more completely classified into four groups as it is presented in Table 1. 
Table 1. Classification of sources (Yamaguchi, 2002)

\begin{tabular}{|c|c|c|}
\hline & Non-renewable sources & Renewable sources \\
\hline $\begin{array}{c}\text { Non-Recyclable products } \\
\text { once consumed }\end{array}$ & $\begin{array}{c}\text { Fossil fuels energies } \\
\text { Nuclear energy }\end{array}$ & $\begin{array}{c}\text { Wind/Solar Hydrogen energies } \\
\text { Geothermal) }\end{array}$ \\
\cline { 2 - 3 } $\begin{array}{c}\text { Recyclable products as } \\
\text { sources }\end{array}$ & Minerals & Forest, Water \\
\hline
\end{tabular}

Finally, let us assume that production and consumption activities generate as byproducts industrial wastes, represented here by carbon dioxide. The increased amount of atmospheric carbon dioxide has a considerable influence on the growth paths, since the economy heavily depends on the use of non-renewable fossil fuels that causes an emission of carbon dioxide and eventually global warming.

\section{The results of simulation}

We considered two possible scenarios of development. In the first optimistic scenario we assume that non-renewable resources are only slightly depleted. The time of population saturation equals 10 years. At the outset, after 100 years of our simulation $2 \%$ of resources are depleted. We observe increase of output (income) over 100 years of simulation, and our economy is growing (Figure 2). Following 30 periods of simulation, savings are very low, and almost all the production is consumed (Figure 3). Production is lower due to lower amount of capital in the production process. In the next period, savings are growing again, due to population saturation.

In the second scenario, we assume that depletion rate of nonrenewable resources is higher than in a first scenario, due to higher costs of using those nonrenewable resources. At the outset, capital is decreased for $65 \%$ over all the period of our simulation. Our economy is growing, but much slower than in the first scenario (Figure 2). Following 30 periods of simulation, savings are very low, but start to increase when population growth is stopped.

As the resources continues its inevitable decline, the input rate of fossil fuels declines due to autonomous technological progress. Further, we allow for the non-renewable resource to be substituted, but even with that energy our resources are depleted. This result should not be surprising. Since the savings are lowered as a result of lower economic output, renewable resources will be depleted when consumption is bigger than zero. 


\section{Conclusion}

The results of simulation support view that growth may lead to the exhaustion of natural resources and deterioration in the environment. A depletion of nonrenewable resources leads to higher prices of those resources, may decrease output and lead consequently to a decrease in population. Economic growth leads not only to the depletion of non-renewable resources, but can also lead to increase of pollution and wastes. We can circumvent such depletion of nonrenewable resources and stay within a limit of resource availability by limitation the inefficient use of fossil-fuels, and common application of renewable sources of energy. Moreover, comprehensive revision of existing policies in rational consumption is necessary. Therefore, emphasis on sufficiency, equity and quality of life rather than quantity of output is necessary.

Particular interest should be put on the influence of technological progress on effective consumption of non-renewable resources and productivity of production factors. It is essential to implement renewable sources of energy, like biomass, together with less capital-consuming technology. The renewable energy will protect us from global warming. To accomplish this goal, we have to follow Brown (2001), who shows how to change the economy. In that new economy, wind farms replace coal mines, hydrogen-powered fuel cells replace internal combustion engines and cities are designed for people, not for cars.
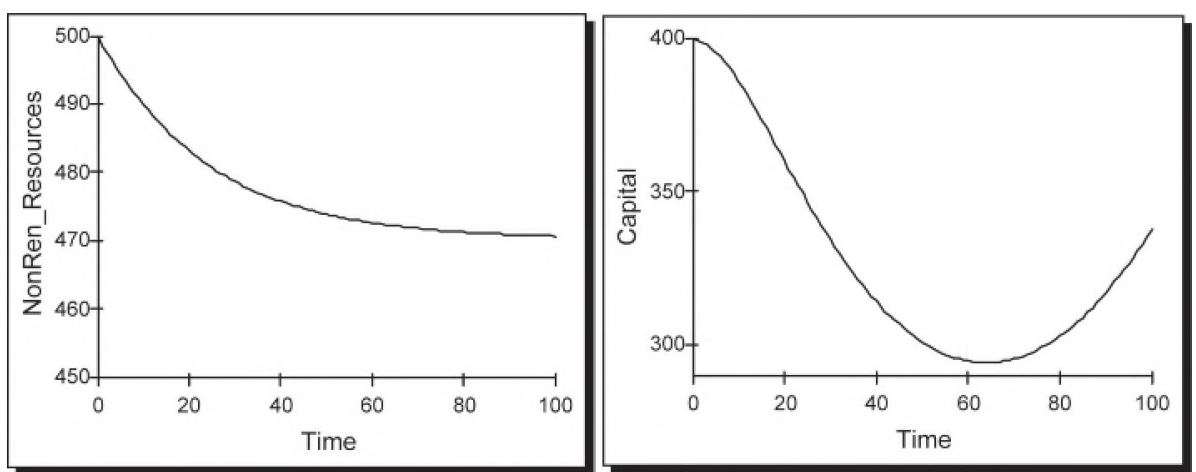

Figure 2. Optimistic scenario: non-renewable resources, and capital 

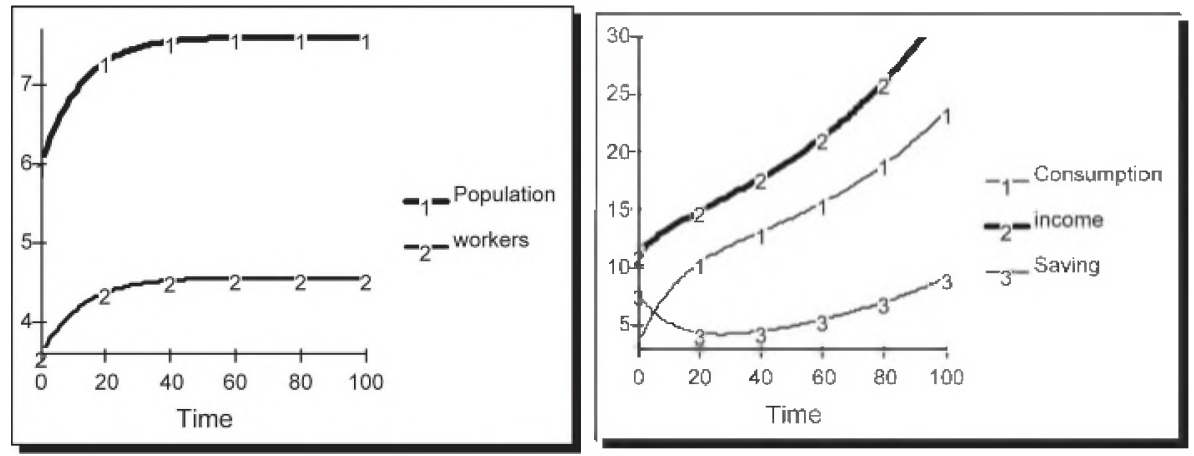

Figure 3. Optimistic scenario: population, workers, consumption, income and savings
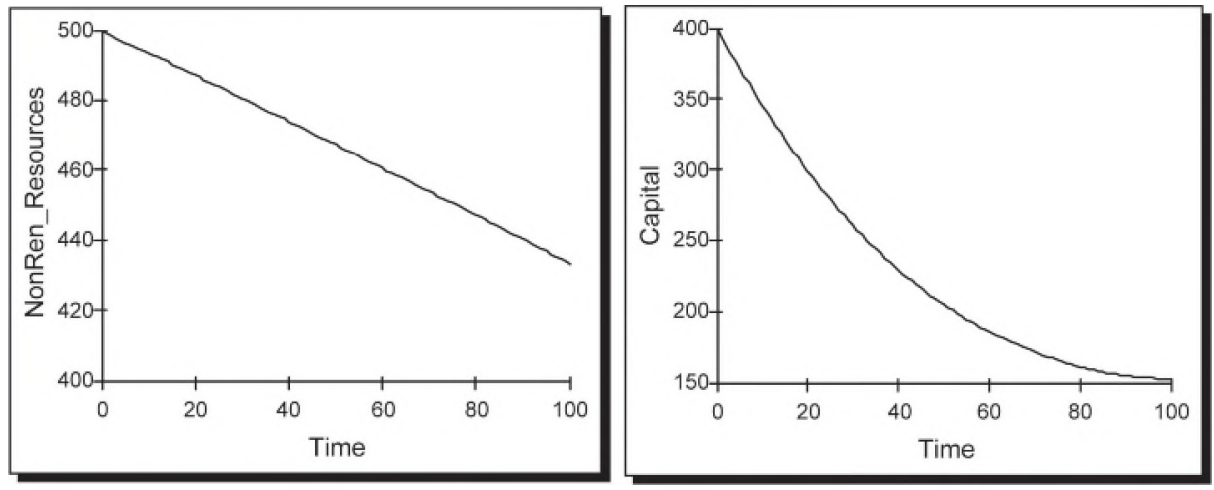

Figure 4. Pessimistic scenario: higher depletion rate of non-renewable resources, and higher decrease of capital
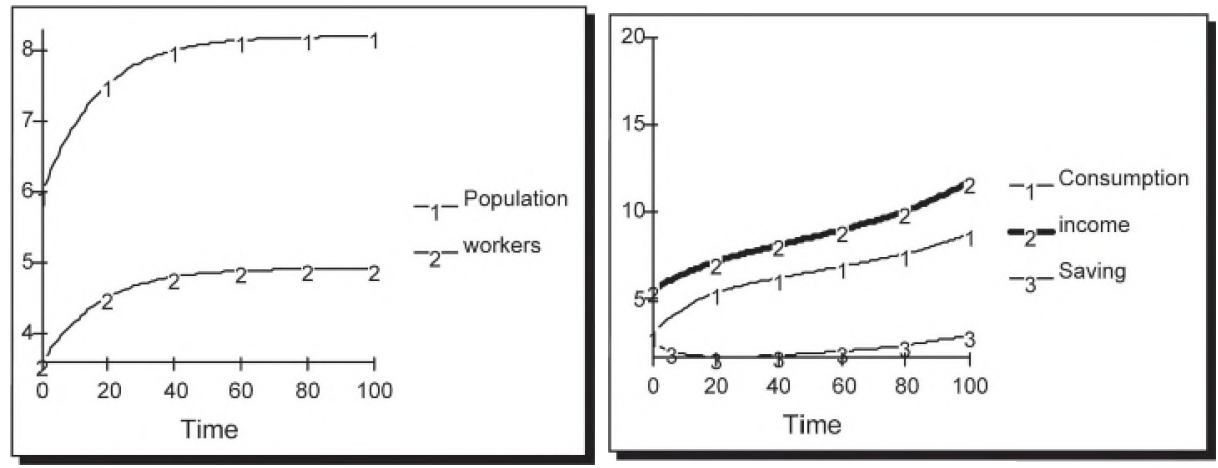

Figure 5. Pessimistic scenario: population, workers, consumption, income and savings References

Acharya, R.; SAEED, K. (1996): An Attempt to operationalize recommendations of 'Limits to 
growth' study to sustain the future of mankind, System Dynamics Review, Vol. 12, no 4., 281301.

Arrow, K. et al. (1995): Economic growth, carrying capacity and the environment. Science 268 (1995) 520-521, reprinted in Ecological Economics 15 (1995) 91-95.

BECKERMANN, W. (1999): A pro-growth perspective in: Handbook of environmental and resource economics, ed. J. C. J.M van den Bergh, Edward Elgar, Cheltenham UK, Northampton MA, USA

Brown, G. M.; FIELD B. (1979): The adequacy of measures for signaling the scarcity of natural resources, in U.K Smith (ed.), Scarcity and Growth Reconsidered, Baltimore, MD: Johns Hopkins University Press, 218-248,

Brown, L. (2001): Eco-Economy, Norton\&Company, New York.

De Bruyn, S. M.; HeintZ, R.J. (1999): The environmental Kuznets Curve hypothesis, in: Handbook of environmental and resource economics, ed. J. C. J.M van den Bergh, Edward Elgar, Cheltenham UK, Northampton MA, USA.

DALY, E.H. (1996): Beyond growth, Beacon Press, Boston,

Deadman, D.; R.K. Turner (1988): Resource conservation sustainability and technical change, in RK Turner (ed.), Sustainable Environmental Management: Principles and Practise, London: Belhaven Press, 67-100

Dinda, S.; Coondoo, D.; Pal M. (2000): Air quality and economic growth: an empirical study, Ecological Economics 34 (2000) 409-423.

Grossman, G. M.; Kreuger, A.(1995): Economic Growth and the Environment, Quarterly Journal of Economics, 110 (2) (1995) 353-377.

HAYAMI, Y. (1997): Development economics from the poverty to the wealth of nations, Clarendon Press, Oxford, England

Helm, D. (2000): Objectives, Instruments and Institutions in Environmental Policy, Oxford: Oxford University Press.

Lovejoy, D. (1996): Limits to growth?, Science and Society 60 (3) 266-278

Meadows, H. D., et al., (1972) The Limits to Growth. A report for the Club of Rome. Project on the predicament of mankind, Universe Books, New York..

Mikeseld, R.F. (1995): The limits to growth a reappraisal, Resources Policy 21 (2) (1995) 127 131.

OpHARDT C. (1997): Human society and environmental impacts global collapse or sustainable future? (http://www.elmhurst.edu/ chm/onlcourse/chm110/labs/limits.html).

Solow, R., (2000): Growth theory. An exposition. Oxford University Press, Oxford.

Stiglitz, J.E (1979): A neoclassical analysis of the economics of natural resources. In: Smith, V.K. (Ed.), Scarcity and growth reconsidered. Resources for the future, Baltimore, 36-66.

Tietenderg, T. (2000), Sustainable development: defining the concept. Environmental and natural resource economics, 5th Ed., Addison-Wesley, Reading, MA, 86-99.

TisDEL, C. (2004): Sustainability: can it be achieved? Is economics the bottom line? in: Handbook of Sustainable Development Planning, M. A. Quaddus and M.A.B. Siddique (Ed.), Edward Elgar, Cheltenham, UK, Northampton, MA, USA, 60-74.

WOODWELL, J.C (1998): A simulation model to illustrate feedbacks among resource consumption, production and factors of production in ecological-economic systems, Ecological Modelling 112 (1998) 227-247.

YAMUGUCHI, K. (2001): A step-by step system dynamics modeling of sustainability. in: Proc. of International Conference of the System Dynamics Society, Atlanta, US.

YAMAguchi, K. (2002): On A System Dynamics Modeling of the Eco-Economy, International Symposium "Scientific Heritage of N.D. Kondratieff in the Context of Development of the Russian and the World Socio-Economic Thought", the Institute of Economics, Russian Academy of Sciences. 
Yamaguchi, K. (2004): Modelling long term sustainability, in: Handbook of Sustainable Development Planning, M. A. Quaddus and M.A.B. Siddique (Ed.), Edwar Elgar, Cheltenham, UK, Northampton, MA, USA, 29-59.

\title{
Wpływ ekonomicznego postępu na jakość środowiska
}

\author{
STRESZCZENIE
}

Wraz z rosnącym zainteresowaniem rozwojem przyjaznych dla środowiska rozwiązań problemów świata, włącznie z pogarszaniem się stanu globalnego środowiska i wahających się ekonomicznych warunków, zapotrzebowanie na metody przewidywania skutków decyzji politycznych staje się coraz bardziej pilne. Ten artykuł analizuje możliwy wpływ rozwoju ekonomicznego na jakość środowiska. Ostrzegamy, że bez znaczących redukcji w przerobie w konkretnym czasie, możemy oczekiwać pokaźnego spadku w głównych działach w produkcji jedzenia, zużycia energii i produkcji przemysłowej. Model przedstawiony w tym artykule powinien ostrzegać podejmujących decyzje o nadchodzącym problemie nagłych ekonomicznych wzrostów na świecie, gdzie zasoby zaczynają być wyeksploatowane. 